\title{
Equilibrium and Kinetic Studies of Cu (II), Cd (II), Pb (II) and Fe (II) Adsorption from Aqueous Solution Using Cocoa (Theobroma cacao) Pod Husk
}

\author{
${ }^{* 1}$ OBIKE, AI; ${ }^{1}$ IGWE, JC; ${ }^{1}$ EMERUWA, CN; ${ }^{2}$ UWAKWE, KJ \\ ${ }^{1}$ Department of Pure \& Industrial Chemistry, Abia State University, Uturu, Abia State, Nigeria \\ ${ }^{2}$ Corrosion and Electrochemistry Research Group, Department of Pure and Applied Chemistry, University of Calabar, Calabar, Nigeria \\ *Corresponding Author Email: anthonyobike@yahoo.com Phone: +234-803-446-7177
}

\begin{abstract}
The potentials of cocoa pod husk to adsorb $\mathrm{Cu}$ (II), Cd (II), $\mathrm{Pb}$ (II) and $\mathrm{Fe}$ (II) ions from aqueous solutions was investigated in a batch system. The effects of contact time, initial metal ion concentration and adsorbent dose on the adsorption capacity of the adsorbent were examined. The percent adsorbed increased as initial metal ion concentration, contact time and adsorbent dose was increased until equilibrium was reached. Langmuir isotherm and pseudo-second order models were used to analyse the equilibrium and kinetic experimental data respectively. Equilibrium experimental data of $\mathrm{Cu}$ (II), $\mathrm{Cd}$ (II), $\mathrm{Pb}$ (II) and $\mathrm{Fe}$ (II) adsorption onto cocoa pod fitted well to Langmuir model and the kinetic data also fitted well to the pseudo-second order model, as indicated by the correlation coefficients. The maximum sorption capacity $\left(\mathrm{q}_{\max }\right)$ ranged as $4.16,4.42,4.69$ and $4.83 \mathrm{mg} / \mathrm{g}$ for Fe (II), $\mathrm{Cd}$ (II), $\mathrm{Cu}$ (II) and $\mathrm{Pb}$ (II) respectively. This study demonstrated that the waste cocoa pod could be used as a potential adsorbent for toxic metals such as $\mathrm{Cu}$ (II), $\mathrm{Cd}$ (II), $\mathrm{Pb}$ (II) and $\mathrm{Fe}$ (II).
\end{abstract}

DOI: https://dx.doi.org/10.4314/jasem.v22i2.5

Copyright: Copyright (C) 2018 Obike et al. This is an open access article distributed under the Creative Commons Attribution License (CCL), which permits unrestricted use, distribution, and reproduction in any medium, provided the original work is properly cited

Dates: First received 10 January 2018; Received in revised form 06 February 2018; Accepted 10 February 2018

Keywords: Adsorption isotherm, Adsorption Kinetic, Cocoa pod, Langmuir isotherm, Pseudo-second order model

Heavy metals have been identified as very dangerous class of environmental pollutants. Heavy metals are natural elements that have been extracted from the earth and harnessed for industrial raw materials and products (Kanamadi et al., 2006). The increased use of metals and chemicals in industries has resulted in the generation of large quantities of effluents containing high levels of toxic heavy metals (Abia and Asuquo, 2006; Liang et al., 2007). Among these heavy metals, copper, cadmium, lead and iron are notable for their wide environmental dispersion from various industrial activities. This in effect increases their tendency to accumulate in selected tissues of the human body and their overall potential to be toxic even at relatively low levels of exposure (Kanamadi et al., 2006; Abia and Asuquo, 2006). Cadmium has been implicated in kidney dysfunction, hepatic damage and hypertension (Klaassen, 2001). Toxic levels of lead affect neurobehavioral development, brain function (Goldstein, 1990; Dietrich et al., 1990) and have been associated with encephalopathy, seizures and mental retardation (Schumann, 1990). Excess copper accumulates in the liver, brain, skin, pancreas and myocardium (Davis, 2000) and the most toxic form of copper is thought to be $\mathrm{Cu}$ (I) (Ho et al., 2002). Iron is a toxic heavy metal that is commonly found in industrial effluents. The presence of iron in water results in undesirable color, odour and taste which makes water unfit for industry use and domestic consumption (Pavani and Sunil Kumar, 2013). The effects of iron exposure on human health include respiratory problems, heart attack, seizures, tissue damage and depression (Kamarudzaman et al., 2013).

Following the need to remove $\mathrm{Cu}$ (II), $\mathrm{Cd}$ (II), $\mathrm{Pb}$ (II) and $\mathrm{Fe}$ (II) from industrial wastewater effluents to reduce environmental pollution, various conventional methods have been developed over the years. These methods include chemical precipitation, ion exchange, oxidation and reduction, fixation or cementation and solvent extraction (Kratochvil et al., 1998; Acosta-Rodriquez et al., 2018). These methods are economically unfavourable or technically complicated (Idris et al., 2012) and are used only in special cases of wastewater treatment (Kratochvil et al., 1998; Sharma, 2003). Recently, attention has been directed towards biosorption as a new technology for removing toxic metals from wastewaters (Acosta-Rodriquez et al., 2012). This is based on the binding capacities of various biological materials (Kanamadi et al., 2006). Biosorption technique is one of the preferred methods for the removal of heavy metals because of its efficiency and 
low cost (Li et al., 2007). Biomass viability does not affect the metal uptake. Therefore, any active metabolic uptake process is currently considered to be a negligible part of biosorption (Acosta-Rodriquez et al., 2012). Recent studies have shown that heavy metals can be removed using biosorption materials, like agricultural by-products (Gardia-Torresday et al., 1999; Sun and Shi, 1998); hazelnut shell (Comino et al., 2000); orange waste (Perez-Marin et al., 2007); tamarind peel (Acosta et al., 2010); groundnut shell (Idris et al., 2012; Choudhury et al., 2012) ; maize cob and husk (Igwe and Abia, 2003); modified corn stalks (Chen et al., 2011); boiler fly ash (Okoronkwo et al., 2008; Okoronkwo et al., 2011); sawdust (Vinodhini and Das, 2010); Zea mays Tassel (Zvinowanda et al., 2010) and so on. Cocoa pod husk has also been used for the sorption of $\mathrm{Al}$ (III), As (V), $\mathrm{Cr}$ (VI) and $\mathrm{Ni}$ (II) (Igwe, 2011). The major advantages of these agricultural by-products are that they are economical, eco-friendly, abundant, renewable and more efficient (Manject et al., 2009). Therefore, the present research studied the removal of $\mathrm{Cu}$ (II), $\mathrm{Cd}$ (II), $\mathrm{Pb}$ (II) and Fe (II) from synthetic aqueous wastewater using cocoa (Theobroma Cacao) pod husk by investigating some process conditions.

\section{MATERIALS AND METHODS}

Preparation of Synthetic Wastewater: Stock solutions $(1000 \mathrm{mg} / \mathrm{L}$ ) of $\mathrm{Cu}$ (II), Cd (II), Fe (II) and $\mathrm{Pb}$ (II) metal ions were prepared by dissolving $3.931 \mathrm{~g}$ of $\mathrm{CuSO}_{4} .5 \mathrm{H}_{2} \mathrm{O} ; 6.84 \mathrm{~g}$ of $\mathrm{CdSO}_{4} .8 \mathrm{H}_{2} \mathrm{O} ; 4.973 \mathrm{~g}$ of $\mathrm{Fe}_{2} \mathrm{SO}_{4} \cdot 7 \mathrm{H}_{2} \mathrm{O}$ and $1.831 \mathrm{~g}$ of $\mathrm{PbOOCCH}_{2} \cdot 3 \mathrm{H}_{2} \mathrm{O}$ respectively in $1 \mathrm{~L}$ of de-ionised water. Serial dilutions were made from the respective stock solutions to obtain the working solution concentrations.

Preparation of Biosorbents: Cocoa pod husks were obtained from a cocoa farm in Isuikwuato L.G.A of Abia State, Nigeria. The cocoa pod husks were washed with distilled water, cut into small pieces and dried under the sun for 15 days. The dried cocoa pod husks were milled in a grinder. It was sieved through $1000 \mu \mathrm{m}$ sieve size and then through $500 \mu \mathrm{m}$ sieve size. The adsorbents retained on the $500 \mu \mathrm{m}$ size were stored in an air-tight plastic container for further use as the adsorbent without any chemical treatment.

Biosorption Experiment: Batch biosorption experiments were carried out using modified method by Qaiser et al., (2007). Average values of all experiments were used in all calculations. To find the equilibrium time for sorption of $\mathrm{Cu}$ (II), $\mathrm{Cd}$ (II), $\mathrm{Pb}$ (II) and Fe (II) on cocoa pod husk, $1 \mathrm{~g}$ of the prepared biosorbent, cocoa pod husk, was mixed with $50 \mathrm{~mL}$ of $\mathrm{Cu}$ (II), Cd (II), $\mathrm{Pb}$ (II) and $\mathrm{Fe}$ (II) $100 \mathrm{mg} / \mathrm{L}$ solutions separately. The mixtures were shaken with a mechanical shaker for different time intervals of 10 to 60 minutes. The samples were filtered thereafter with a suction pump.

The effect of biosorbent dose was determined by varying the adsorbent loading from $1 \mathrm{~g}$ to $12 \mathrm{~g}$ in 100 $\mathrm{mL}$ of the metal ions solutions of $100 \mathrm{mg} / \mathrm{L}$ initial concentration and the biosorption experiment carried out using constant metal ion-substrate contact time of $90 \mathrm{~min}$ at ambient temperature of $35^{\circ} \mathrm{C}$. At the end of the experiments, the samples were filtered with a suction pump.

The initial concentrations of the metal ions solutions were varied from $10 \mathrm{mg} / \mathrm{L}$ to $100 \mathrm{mg} / \mathrm{L}$. Using an adsorbent dose of $1 \mathrm{~g}$, constant $\mathrm{pH}$ of the solutions of 7.5 , and constant metal ion-substrate contact time of 90 mins, the biosorption experiment was carried out to determine the effect of initial metal ion concentration on the adsorption. The samples were filtered thereafter with a suction pump. A control flask containing only the $\mathrm{Cu}$ (II), $\mathrm{Cd}$ (II), $\mathrm{Pb}$ (II) and Fe (II) solutions with no adsorbent were used to determine the initial concentrations of the metal solutions and eliminate any sorption that might have occurred by the glass wares.

Analytical Method: The filtrates in all the experimental runs and the control were analyzed using a Shumadzu 6650 AAS model to determine the concentration of metal left after sorption.

The amount of metal removed was calculated by:

$\%$ Removal $=100 \times\left(C_{i}-C_{e}\right) / C_{i}$

Where $\mathrm{C}_{\mathrm{i}}=$ Initial concentration and $\mathrm{C}_{\mathrm{e}}=$ Final concentration. The sorption capacity ' $\mathrm{q}$ ' was calculated with the formula:

$\mathrm{q}=\mathrm{V}\left(\mathrm{C}_{\mathrm{i}}-C_{e}\right) / m$

Where $\mathrm{V}=$ Volume of the solution; $\mathrm{C}_{\mathrm{i}}=$ Initial concentration; $\mathrm{C}_{\mathrm{e}}=$ Final concentration and $\mathrm{m}=$ Dry weight of the biosorbent.

\section{RESULTS AND DISCUSSION}

Effect of Adsorbent Dose: The effect of adsorbent dose on $\mathrm{Cu}$ (II), $\mathrm{Cd}$ (II), $\mathrm{Pb}$ (II) and $\mathrm{Fe}$ (II) adsorption onto cocoa pod husk are shown in Figure 1. It could be observed that the percentage removal of each metal increased rapidly to $1 \mathrm{~g}$ after which further 
increase in adsorbent dose showed no significant effect on the percentage removal. However, for $\mathrm{Cu}$ (II) there was a slight decrease between $1 \mathrm{~g}$ to $4 \mathrm{~g}$ after which percentage removal became fairly constant. Initial increase in adsorption with adsorbent dose can be attributed to increased adsorption surface area and availability of more adsorption sites (Wasewar et al., 2009). The percentage adsorbed remain fairly constant even at increasing adsorbent dosage could be attributed to small concentration of metal ions remaining in solution available for biosorption and exhaustion of the adsorbents as seen in Figure 1. Similar results have been reported (Choudhury et al., 2012; Nameni et al., 2008; Elaigwu et al., 2010; Igwe et al., 2011). Saueprasearsit et al., (2010), reported that increasing adsorbent dose increases amount adsorbed but decreases adsorption density. This is mainly because of unsaturation of adsorption sites (Pehilivan et al., 2008). This could also be due to particle interaction such as aggregation resulting from high adsorbent dose. This leads to decrease in total surface area of the adsorbent and an increase in diffusion path length (Shukla et al., 2002). Hence, the decrease in adsorption at high adsorbent dose.

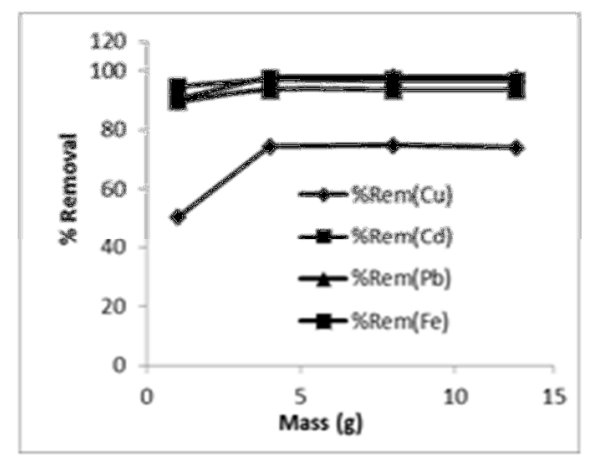

Fig 1: Effect of adsorbent dose on adsorption onto cocoa pod husk

Effect of Contact Time: Biosorption of $\mathrm{Cu}$ (II), $\mathrm{Cd}$ (II), $\mathrm{Pb}$ (II) and $\mathrm{Fe}$ (II) at various contact time of 10 to 60 mins onto cocoa pod husk are shown in Figure 2. The initial adsorptions for the four metals were rapid within 10 mins after which change in contact time yielded no significant change in the adsorption. However, the percentage removal of $\mathrm{Cu}$ (II), Cd (II) and $\mathrm{Pb}$ (II) were higher than $\mathrm{Fe}$ (II). The initial rate of adsorption of the metals may be explained by the fact that initially for adsorption, large vacant sites were available which slowed down later due to exhaustion of remaining surface site (Saravanane $e t$ al., 2002) and sorption process could be said to have attained equilibrium. Further increase in contact time did not increase the percent (\%) adsorption capacity of the metal ions as seen in Figure 2. Hussain et al., (2009) reported initial rapid adsorption and attainment of equilibrium at about $50 \mathrm{mins}$ for sorption of $\mathrm{Pb}$ (II) using non-living biomass of Spirogyra neglecta. Similar results have also been reported (Okoronkwo et al., 2008; Okoronkwo et al., 2011). Zvinowanda et al (2009) in the removal of $\mathrm{Cr}$ (VI) using maize tassel reported that equilibrium was established at the surface of the adsorbent after sometime or it can be spontaneous. Hassan et al., (2008) in removal of $\mathrm{Cr}$ (VI) using maize bran reported that the extent of sorption increased rapidly in the initial stages but became slow in the later stages until the attainment of equilibrium and that equilibrium time was independent of initial sorbate concentration. Also, the rate of biosorption of metal ions has been reported to be biphasic (Liu et al., 2006). The initial fast phase occurs due to surface adsorption on the biomass. The subsequent slow phase occurs due to diffusion of the metal ions into the inner part of the biomass (Babarinde et al., 2007).

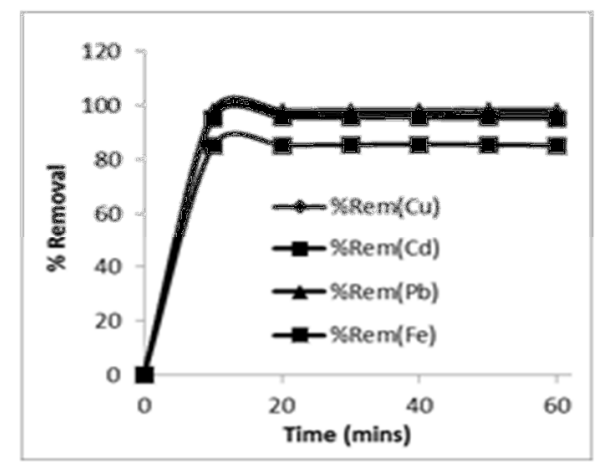

Fig 2: Effect of contact time on adsorption of metal ions onto cocoa pod husk.

Effect of Initial Metal Ion Concentration: The effect of initial metal ion concentration of $\mathrm{Cu}$ (II), Cd (II), $\mathrm{Pb}$ (II) and $\mathrm{Fe}$ (II) adsorption onto cocoa pod husk are shown in Figure 3. From the plots, it could be seen that the percentage removal of the four metals increased with increase in initial metal ion concentration. The increase was rapid from $10 \mathrm{mg} / \mathrm{L}$ to $20 \mathrm{mg} / \mathrm{L}$ for all metal ions. For $\mathrm{Cu}$ (II), $\mathrm{Pb}$ (II) and $\mathrm{Fe}$ (II), the increase slowed down from $20 \mathrm{mg} / \mathrm{L}$ to 30 $\mathrm{mg} / \mathrm{L}$. For $\mathrm{Fe}$ (II) and $\mathrm{Pb}$ (II), there was a slight decrease from $30 \mathrm{mg} / \mathrm{L}$ to $40 \mathrm{mg} / \mathrm{L}$ after which further increase in metal ion concentration had no significant effect on the percentage removal. As initial metal ion concentration increased from 20 $\mathrm{mg} / \mathrm{L}$ and $30 \mathrm{mg} / \mathrm{L}$ for $\mathrm{Cd}$ (II) and $\mathrm{Fe}$ (II) respectively, there was no significant change in the percentage removal. The initial increase in the percentage removal could be attributed to the decrease in resistance for the uptake of solute from 
solution with increase in metal concentration (Wasewar et al., 2009).

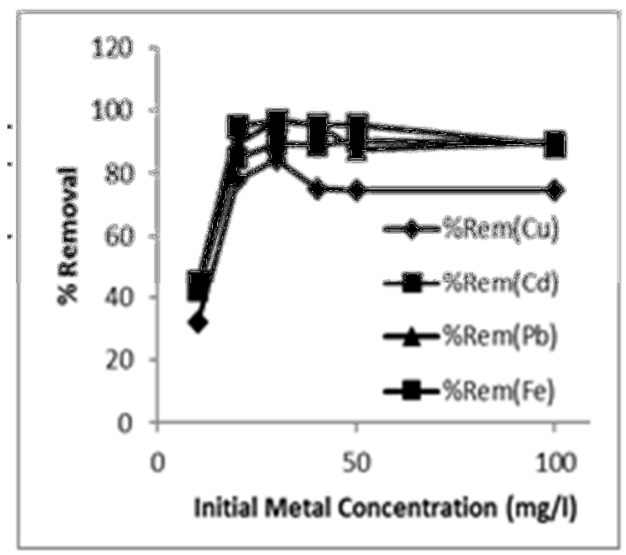

Fig 3: Effect of initial metal ion concentration on adsorption onto cocoa pod husk

Also, this sorption characteristic indicated that surface saturation was dependent on the initial metal ion concentration (Babalola et al., 2008). At low concentrations, sorption sites took up the available metals quickly. But at higher concentrations, metal ions needed to diffuse to the biomass surface by intraparticle diffusion and greatly hydrolyzed ions will diffuse at a slower rate (Zafar et al., 2006), hence reduced sorption rate.

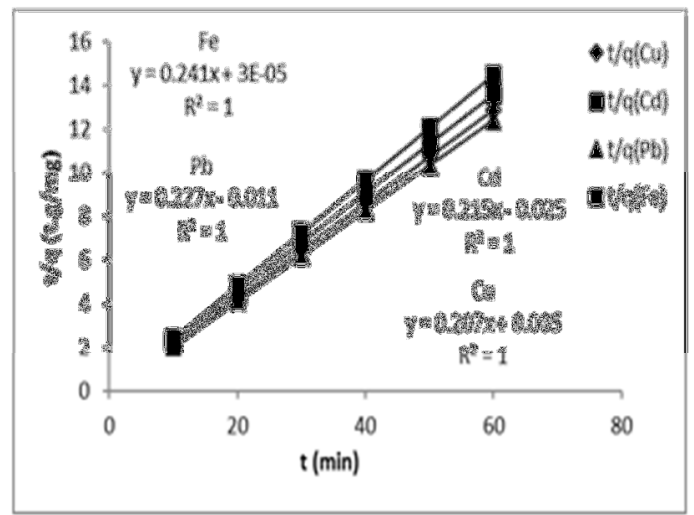

Fig 4: Pseudo second order plot $\mathrm{Cu}$ (II), Cd (Ii), Pd (II) and Fe (II) adsorption onto cocoa pod husk.

Table 1: Pseudo Second Kinetics' Parameters

\begin{tabular}{llll}
\hline Metal & $\mathrm{K}_{2 . a d s}$ & $\mathrm{q}_{\mathrm{e}}$ & $\mathrm{R}^{2}$ \\
\hline $\mathrm{Cu}$ (II) & 8.5731 & 4.83 & 1.000 \\
$\mathrm{Cd}(\mathrm{II})$ & -1.8499 & 4.65 & 1.000 \\
$\mathrm{~Pb}(\mathrm{II})$ & -4.6957 & 4.40 & 1.000 \\
$\mathrm{Fe}(\mathrm{II})$ & $1.9335 \times 10^{3}$ & 4.15 & 1.000 \\
\hline
\end{tabular}

OBIKE, AI; IGWE, JC; EMERUWA, CN; UWAKWE, KJ
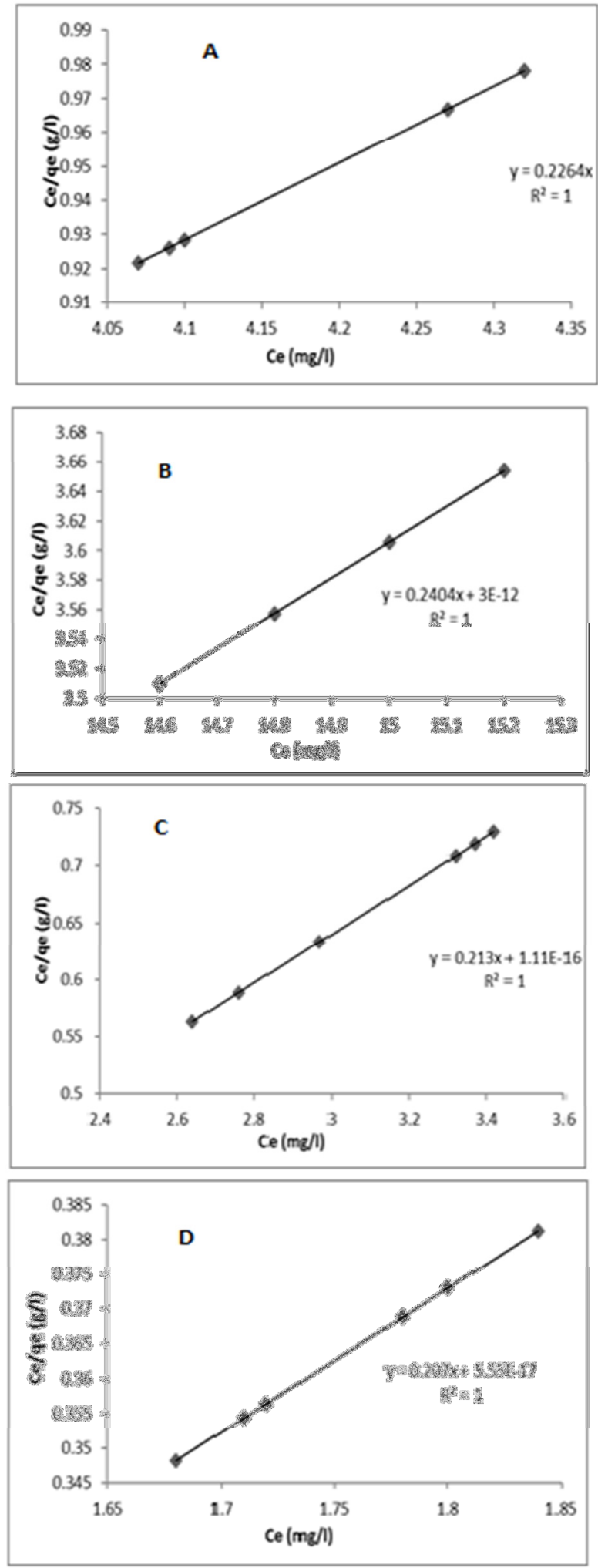

Fig 5: Langmuir isotherm plot of (a) $\mathrm{Cd}$ (II), (b) $\mathrm{Cu}$ (II), (c) $\mathrm{Fe}$ (II) and (d) $\mathrm{Pb}$ (II) adsorption onto cocoa pod husk. 
Again, this could be due to the increase in the number of ions competing for the available functional groups on the surface of the biomass (Agarwal et al., 2006). Similar results have also been reported such as in the adsorption of hexavalent chromium using wheat bran (Nameni et al., 2008); adsorption of Cr (VI), Ni (II) and $\mathrm{Al}$ (III) ions using cocoa pod husk (Igwe et al., 2011); biosorption of $\mathrm{Zn}$ (II) on maize wrapper (Babarinde et al., 2008); hexavalent chromium removal using Litchi chinensis (Acosta-Rodriquez et al., 2012)

Adsorption Kinetics: The kinetics of metal ion sorption has been described as a very important parameter for designing sorption systems. The reactor configuration also depends on the rate of sorption in addition to sorption capacity.

A rapid kinetics will facilitate smaller reactors while a slow rate of uptake will require long columns to utilize maximum potential of the biosorbent. The rate of sorption onto a sorbent surface depends on a number of factors such as structural properties of the sorbent, initial concentration of the solute and the interaction between the solute and the active sites of the sorbent (Vinodhini and Das, 2010).

The experimental data were analysed using pseudo second order kinetics model (Ho, YS; McKay, 2004), which can be expressed as follows:

$$
\mathrm{t} / \mathrm{q}_{\mathrm{t}}=1 / \mathrm{K}_{2 \mathrm{ads}} \cdot \mathrm{q}_{\mathrm{e}}^{2}+\mathrm{t} / \mathrm{q}_{\mathrm{e}}
$$

Where $\mathrm{K}_{2 . \text { ads }}$ is the pseudo-second order kinetics constant $\left(\mathrm{g} \cdot \mathrm{mg}^{-1} \cdot \mathrm{min}^{-1}\right)$. The linear plot of $\mathrm{t} / \mathrm{q}_{\mathrm{t}}$ versus $\mathrm{t}$ for $\mathrm{Cu}$ (II), $\mathrm{Cd}$ (II), $\mathrm{Pb}$ (II) and Fe (II) are shown in Figure 4.

The values of $\mathrm{K}_{2 \text {.ads }}$ and $\mathrm{q}_{\mathrm{e}}$ were calculated from the slopes and intercepts of the plot. The values obtained are depicted in Table 1.

Adsorption Isotherm: The analysis of equilibrium adsorption data by fitting them to different isotherm models is an important step to find the suitable model that can be used for design purposes (Haghseresht and Lu, 1998).

The Langmuir model was employed in this study. The linearized form of the Langmuir isotherm model is represented by the equation (Langmuir, 1918):

$$
\mathrm{C}_{\mathrm{e}} / \mathrm{q}_{\mathrm{e}}=1 / \mathrm{K}_{\mathrm{L}} \cdot \mathrm{q}_{\max }+\mathrm{C}_{\mathrm{e}} / \mathrm{q}_{\max }
$$

Where $\mathrm{q}_{\mathrm{e}}$ is the equilibrium solid phase metal ion concentration on the adsorbent (mg. $\left.\mathrm{g}^{-1}\right), \mathrm{C}_{\mathrm{e}}$ is the equilibrium liquid phase metal ion concentration in the solution $\left(\mathrm{mg} . \mathrm{l}^{-1}\right), \quad \mathrm{q}_{\max }$ in the maximum biosorption capacity of adsorbent $\left(\mathrm{mg}^{-\mathrm{g}^{-1}}\right)$ and $\mathrm{K}_{\mathrm{L}}$ is the Langmuir biosorption constant (L.mg

It is well known that the Langmuir equation is intended for a homogeneous surface. A good fit of this equation reflects monolayer adsorption (Fytianos et al., 2000).

Values of Langmuir parameters $\mathrm{q}_{\max }$ and $\mathrm{K}_{\mathrm{L}}$ were calculated from the slopes and intercepts of the linear plot of $\mathrm{C}_{\mathrm{e}} / \mathrm{q}_{\mathrm{e}}$ against $\mathrm{C}_{\mathrm{e}}$ as shown in Figures 5, 6, 7 and 8 for $\mathrm{Cu}$ (II), $\mathrm{Cd}$ (II), $\mathrm{Pb}$ (II) and $\mathrm{Fe}$ (II) respectively.

The parameters obtained are listed in Table 2. It could be seen that the Langmuir isotherm gave a very good fit to the equilibrium sorption experimental data, going by the values of the coefficient of determination $\left(\mathrm{R}^{2}\right)$ shown in Table 2 .

Langmuir isotherm model have been used to model sorption experiments (Sirajudeen et al., 2013; Sharawy et al., 2013) and have been reported to give a good fit to some sorption systems (Nameni et al., 2008; Hassan et al., 2008). Table 3 below shows a summary of the comparism between the results of the maximum sorption capacity from this study and that reported in the literature.

It could be seen that the values of the maximum sorption capacity $\mathrm{q}_{\max }$ from this work, compares favourably with that reported in literature by other researchers.

Table 2: Langmuir Isotherm Parameters

\begin{tabular}{llll}
\multicolumn{4}{l}{ Table 2: Langmuir Isotherm Parameters } \\
\hline Metal ions & $\mathrm{K}_{\mathrm{L}}\left(\mathrm{dm}^{3} / \mathrm{mg}\right)$ & $\mathrm{q}_{\max }(\mathrm{mg} / \mathrm{g})$ & $\mathrm{R}^{2}$ \\
\hline $\mathrm{Cu}(\mathrm{II})$ & $1.92 \times 10^{15}$ & 4.69 & 1.000 \\
$\mathrm{Cd}(\mathrm{II})$ & $2.82 \times 10^{12}$ & 4.42 & 1.000 \\
$\mathrm{~Pb}(\mathrm{II})$ & $3.73 \times 10^{15}$ & 4.83 & 1.000 \\
$\mathrm{Fe}(\mathrm{II})$ & $2.40 \times 10^{11}$ & 4.16 & 1.000 \\
\hline
\end{tabular}


Table 3: Comparism of $\mathrm{q}_{\max }$ reported in literature and that from this study

\begin{tabular}{|c|c|c|c|c|c|c|}
\hline \multirow[t]{2}{*}{$S / N$} & Adsorbent & \multicolumn{4}{|c|}{ Metal ions $\left(q_{\max }\right)(\mathrm{mg} / \mathrm{g})$} & \multirow[t]{2}{*}{ Reference } \\
\hline & & $\mathrm{Cu}$ (II) & $\mathrm{Cd}$ (II) & $\mathrm{Pb}$ (II) & $\mathrm{Fe}$ (II) & \\
\hline 1 & Luffa cylindrical fibre & - & - & 4.63 & - & (Saueprasearsit et al., 2010) \\
\hline 2 & Almond shells & - & - & 2.00 & - & (Mehrasbi et al., 2009) \\
\hline 3 & Orange peel & 44.28 & - & - & - & (Feng et al., 2009) \\
\hline 4 & Dried sunflower leaves & 89.37 & - & - & - & (Benaissa and Elouchdi, 2007) \\
\hline 5 & Olive cake & - & 65.4 & - & - & (Al-Anber and Matoug, 2008) \\
\hline 6 & Sugar beet pulp & - & 46.1 & 43.5 & - & (Pehlivan et al., 2008) \\
\hline 7 & Lady fern (Athyrium-felix-femina) & 0.073 & - & - & - & (Asiagwu et al., 2012) \\
\hline 8 & Maize leaf & - & 10.179 & - & - & (Babarinde et al., 2007) \\
\hline 9 & Calcium carbonate & 569.93 & 1068.63 & 1551.62 & 502.98 & (Ahmad et al., 2012) \\
\hline 10 & $\begin{array}{l}\text { Modified Loquat (Eriobotrya japonica) } \\
\text { leaves }\end{array}$ & 29.67 & - & - & - & (Awwad and Salem, 2012) \\
\hline 11 & Basella alba $\mathrm{L}$ & - & - & 149.25 & - & (Babalola et al., 2008) \\
\hline 12 & Grape stalk & - & - & 9.15 & - & (Martinez et al., 2006) \\
\hline 13 & Peat & 8.4 & 83.5 & - & - & (Koivula et al., 2009) \\
\hline 14 & Tea waste & 48.0 & - & 65.0 & - & (Amarasinghe and Williams, 2007) \\
\hline 15 & Psidium guvajava leaf powder & - & 31.15 & - & - & (Rao et al., 2010) \\
\hline 16 & Wheat bran & - & 15.71 & - & - & (Nouri et al., 2007) \\
\hline 17 & Spent tea leaves & 90.00 & - & - & - & (Bajpai and Jain, 2010) \\
\hline 18 & Maize cob & - & 1.98 & 1.89 & - & (Igwe and Abia, 2007) \\
\hline 19 & Cocoa pod husk & 4.69 & 4.42 & 4.83 & 4.16 & (This study) \\
\hline
\end{tabular}

Conclusion: Adsorption studies for the removal of $\mathrm{Cu}$ (II), $\mathrm{Cd}$ (II), $\mathrm{Pb}$ (II) and $\mathrm{Fe}$ (II) from synthetic wastewater were carried out using cocoa pod as adsorbent. The effects of various parameters; contact time, adsorbent dose and initial metal ion concentration were studied. The study showed the adsorption potentials of cocoa pod for the removal of the four metals studied. Using the correlation coefficient, $\mathrm{R}^{2}$, Kinetics studies showed that the adsorption of the four metals followed pseudo second order kinetics. On the basis of correlation coefficient, $\mathrm{R}^{2}$, it was clear that the Langmuir isotherm fitted the sorption of the four metals studied onto cocoa pod. The results of this study showed that cocoa pod can be efficiently used as a low-cost alternative for the removal of $\mathrm{Cu}$ (II), $\mathrm{Cd}$ (II), $\mathrm{Pb}$ (II) and $\mathrm{Fe}$ (II) from aqueous solutions.

\section{REFERENCES}

Abia, AA; Asuquo, ED (2006). Lead (II) and Nickel (II) adsorption kinetics from aqueous metal solutions using chemically modified and unmodified agricultural adsorbent. Afr. $J$. Biotechnol. 5(16): 1475-1482.

Acosta, I; Lopez, V; Coronado, E; Cardenas, JF; Martinez, VM (2010). Remocion de cromo (VI) por la biomasa de la cascara de tamarindo, (Tamarindus indica). Revista Biotecnol. Bioinge.

14(3): 11-23.

Acosta-Rodriquez, I; Martinez-Perez, R; CardenasGonzalez, JF; Moctezuma- Zarate, M MartinezJuarez, VM (2012). Hexavalent chromium removal by litchi chinensis soon peel. Am. J. Biochem \& Biotech. 8(1): 7-13.
Agarwal, GS; Kumar, H; Chaudari, S (2006). Biosorption of aqueous chromium (VI) by tamarindus indica seeds. Bioresource Technol. 97: 949-956.

Ahmad, K; Bhatti, IA; Muneer, M; Iqbal, M; Iqbal, Z (2012). Removal of heavy metal ( $\mathrm{Zn}, \mathrm{Cr}, \mathrm{Pb}, \mathrm{Cd}$, $\mathrm{Cu}$ and $\mathrm{Fe}$ ) in aqueous media by calcium carbonate as an adsorbent. J. Chem. Biochem. Sci. 2: 48-53.

Al-Anber, ZA; Matoug, MAD (2008). Batch adsorption of cadmium ions from aqueous solution by means of olive cake. J. Hazard. Mater. 151: 194-201.

Amarasinghe, BMWPK; Williams, RA (2007). Tea waste as a low-cost adsorbent for the removal of $\mathrm{Cu}$ and $\mathrm{Pb}$ from waste water. Chem. Eng. J. 132: 299-309.

Asiagwu, Ak; Owamah, IH; Otutu, JO (2012). Kinetic model for the sorption of $\mathrm{Cu}$ (II) and $\mathrm{Zn}$ (II) using lady fern (arthyrium-filix-femina) leaf waste biomass from aqueous solution. Chem. and Process Eng. Res. 3: 1-9.

Awwad, AM; Salem, NM (2012). Biosorption of copper (II) and lead (II) ions from Aqueous solutions by modified loquat (eriobotrya japonica) leaves (MLL). J. Chem. Eng. And Mater. Sci.

3(1): 7-17. 
Babalola, JO; Babarinde, NAA; Oninia, VO; Popoola, OA (2008). Kinetics, equilibrium and thermodynamics studies of the biosorption of lead (II) and chromium (III) by Basella alba L. Pac. J. Sci. Technol. 9 (2): 610-620.

Babarinde, NAA; Babalola, JO; Adebisi, OB (2008). Kinetic, isotherm and thermodynamic studies of the biosorption of zinc (II) from solution by maize wrapper. Int. J. of Physical Sciences. 3(2): 050-055.

Babarinde, NAA; Babalola, JO; Sanni, SO (2007). Isotherm and thermodynamic studies of the biosorption of $\mathrm{Cd}$ (II) from solution by maize leaf. Int. J. Phy. Sci. 2(8): 207-211.

Bajpai, SK; Jain, A (2010). Removal of copper (II) from aqueous solution using spent tea leaves (STL) as a potential sorbent. Water SA. 36(2): 221-228.

Benaissa, H; Elouchdi, MA (2007). Removal of copper ions from aqueous solutions by dried sunflower leaves. Chem. Eng. Process. 46(7): 614-622.

Chen, S; Yue, Q; Gao, B; Li, Q; Xu, X (2011). Removal of $\mathrm{Cr}$ (VI) from aqueous solution using modified corn stalks characteristic, equilibrium, kinetic and thermodynamic study. Chem. Eng. J. 168: 909-917.

Choudhury, TR; Pathan, KM; Amin, MdN; Ali, M; Quraishi, SB; Mustafa, A (2012). Adsorption of $\mathrm{Cr}$ (III) from aqueous solution by groundnut shell. J. Environ. Sci. Wat. Res. 1(6): 144-150.

Comino, G; Passerini, A; Toscano, G (2000). Removal of toxic cations and $\mathrm{Cr}$ (VI) from aqueous solution by hazelnut shell. Water Research. 34: 2955-2962.

Davis, JA; Volesky, B; Vierra, RH (2000). Sargassum seaweed as bio sorbent for heavy metals.

Water Res. 34(17): 4270-4278.

Dietrich, KN; Succop, PA; Bornschein, RL; Kraft, $\mathrm{KM}$; Berger, O; Hammond, PB; Buncher, CR (1990). Lead exposure and neurobehavioral development in later infancy. Environ. Health Perspect. 89: 13-19.

Elaigwu, SE; Usman, LA; Awolola, GV; Adebayo, GB; Ajayi, RMK (2010). Adsorption of Pb (II) from aqueous solution by activated carbon prepared from cow dung. Environ. Research Journal. 4(4): 257-260.

Feng, NC; Guo, XY; Liang, S (2009). Kinetic and Thermodynamic studies on biosorption of $\mathrm{Cu}$ (II) by chemically modified orange peel. Trans. Nonferrous Metals Society of China. 19: 13651370 .

Fytianos, K; Voudrias, E; Kokkalis, E (2000). Sorption-desorption behaviour of 2,4dichlorophenol by marine sediments. Chemosphere. 40: 3-6.

Gardia-Torresday, JL; Tiemann, KJ; Gamez, G; Dokk, D (1999). Effect of chemical competition for multi-metal binding by Medicago sativa (alfalfa). J. Hazard.Mater. 69: 41-51.

Goldstein, GW (1990). Lead poisoning and brain cell function. Environ Health Perspect. 89: 91-94.

Haghseresht, F; Lu, G (1998). Adsorption characteristics of phenolic compounds onto coalreject-derived adsorbent. Energy Fuels. 12: 1100-1107.

Hassan, SH; Singh, KK; Prakash, O; Talat, M; Ho, YS (2008). Removal of Cr (VI) from aqueous solutions using agricultural waste maize bran. $J$. of Hazard. Mater. 152: 356-365.

Ho, YS; Huang, CT; Huang, HW (2002). Equilibrium sorption isotherm for metal ions on tree fern. Process Biochem. 37: 1421-1430.

Ho, YS; McKay, G (2004). Sorption of copper (II) from aqueous solution by peat. Water Air Soil Pollut. 158: 77-97.

Hussain, MA; Salleh, A; Milow, P (2009). Characterization of the adsorption of the lead (II) by the nonliving biomass Spirogyra neglecta (Hasall) kutzing. Am. J. Biochem \& Biotech. 5(2): 75-

83.

Idris, S; Iyaka, YA; Duada, BE; Ndamitso, MM; Umar, MT (2012). Kinetic study of utilizing groundnut shell as ab adsorbent in removing chromium and nickel from dye effluent. ACS J.

2(1): 13-24. 
Igwe, JC (2011). Equilibrium and Kinetic studies of $\mathrm{Al}, \mathrm{Cr}, \mathrm{As}$ and $\mathrm{Ni}$ removal from aqueous, solution using cocoa (Theobroma cocoa) pod husk. PhD Thesis, University of Port Harcourt,

Nigeria.

Igwe, JC; Abia, AA (2007). Adsorption isotherm studies of $\mathrm{Cd}$ (II), $\mathrm{Pb}$ (II) and $\mathrm{Zn}$ (II) ions bioremediation from aqueous solution using unmodified and EDTA-modified maize cob.

Eclectica Quimica. 32(1): 33-42.

Igwe, JC; Abia, AA (2003). Maize cob and husk as adsorbents or removal of $\mathrm{Cd}, \mathrm{Pb}$, and $\mathrm{Zn}$ ions from waste water. The physical Sci. 2: 83-94.

Igwe, JC; Abia, AA; Nwankwo, SO (2011). Bioremediation of $\mathrm{Al}$ (III), Cr (VI) and Ni (II) ions from aqueous solution using cocoa pod husk: Kinetic and intraparticle diffusivities. Bioremediation, Biodiversity Bioaccumulation. 5(1): 28-35.

Igwe, JC; Abia, AA; Okereke, FH (2011). Kinetic studies on the sorption of $\mathrm{Ag}^{+}$and $\mathrm{Al}^{3+}$ from aqueous solution by coconut fibre. Terrestial Aquat. Environ. Toxicology. 5(1): 19-24.

Kamarudzaman, AN; Chay, TC; Ab Jalil, MF; Talib, SA (2013). Biosorption of iron (III) from aqueous solution using pleurotus ostreatus spent mushroom compost as biosorbent. Adv Mat Res. 781-784.

Kanamadi, RD; Ahalya, N; Ramachandra, TV (2006). Biosorption of Heavy Metals by Low Cost Adsorbents. Energy and Wetlands Research. 112: 1-30.

Klaassen, CD (2001). Heavy metals and Health. Hardmen J.G., Limbird L.E., Gilman A.G. (eds). Goodman and Gilmans: The pharmacological basis of Therapeutics. McGraw Hill, New York, pp. 1851-1875.

Koivula, MP; Kajala, K; Ronkomaki, H; Makela, M (2009). Sorption of $\mathrm{Pb}$ (II), Cr (III), Cu (II), As (III) to peat, and utilization of the sorption properties in industrial waste landfill hydraulic barrier layers. J. Hazard. Mater. 164: 345-352.

Kratochvil, D; Pimentel, P; Volesky, B (1998). Removal of trivalent and hexavalent chromium by seaweed biosorbent. Environ. Sci. Technol. 32(18): 2693-2698.
Langmuir, I (1918). The adsorption of gases on plane surface of glass, mica and platinum. J. Am. Chem. Soc. 40: 1361-1403.

Li, Q; Zhai, J: Zhang, W; Wang, M; Zhou, J (2007). Kinetic studies of adsorption of $\mathrm{Pb}$ (III), $\mathrm{Cr}$ (III) and $\mathrm{Cu}$ (II) from aqueous solution by sawdust and modified peanut husk. J. Hazard. Mater. 144(1): 163-167.

Liang, S; Gue, X; Feng, N; Tian, Q (2007) Adsorption of Copper and Cadmium ions from aqueous solution by chemically modified orange Peel. National Natural Science Foundation. 1-10.

Liu, Y; Chang, X; Guo, Y; Meng, S (2006). Biosorption and Preconcentration of lead and cadmium on waste Chinese herb. Pang da hai. $J$. Hazard. Mater. B135: 389-394.

Manject, B; Diwan, S; Garg, VK; Pawan, R (2009). Use of Agricultural waste for the removal of nickel ions from aqueous solutions: Equilibrium and kinetics studies. Int. J. Environ. Sci. Eng. 1: 108-114.

Martinez, M; Miralles, N; Hidalgo, S; Fiol, N; Villaescusa, I (2006). Removal of lead (II) and cadmium (II) from aqueous solutions using grape stalk waste. J. Hazard. Mater. 133(1-3): 203211.

Mehrasbi, MR; Farahmandkia, Z; Taghibeigloo, B; Taromi, A (2009). Adsorption of lead and cadmium from aqueous solution by using almond shells. Water Air Soil Pollut. 199(1-4): 1573-2932.

Nameni, M; Alavi Moghadan, MR; Arami, M (2008). Adsorption of hexavalent chromium from aqueous solution by wheat bran. Int. J. Environ. Sci. Tech. 5(2): 161-168.

Nouri, L; Ghodbane, I; Hamdaoui, O; Chiha, M (2007). Batch sorption dynamics and equilibrium for the removal of cadmium ions from aqueous phase using wheat bran. J. Hazard. Mater. 149: 115-125.

Okoronkwo, NE; Igwe, JC; Aniekwu, CC (2011). Effects of adsorbent activation on Bioremediation of $\mathrm{Hg}$ (II) and $\mathrm{Cd}$ (II) ions from aqueous solution using boiler fly ash Bioremed. Biodiv.Bioavail.. 5(1): 36-45. 
Okoronkwo, NE; Igwe, JC; Ogbonna, HI (2008). Detoxification of $\mathrm{Hg}^{2+}, \mathrm{Cd}^{2+}$ and $\mathrm{Fe}^{2+}$ from aqueous solution using waste boiler fly ash. Terrest. Aquat. Environ. Toxicol. 2: 49-53.

Pavani, KV; Sunil Kumar, N (2013). Adsorption of iron and synthesis of iron nanoparticles by Aspergillus species Kvp 12. Am. J. Nano.Mater. 1(2): 24-26.

Pehilivan, E; Altun, T; Parlayici, S (2008). Utilization of barley straws as biosorbents for $\mathrm{Cu}^{2+}$ and $\mathrm{Pb}^{2+}$ ions. J. Hazard. Mater. 164: 982986.

Pehlivan, E; Yanik, BH; Ahmetli, G; Pehlivan, M (2008). Equilibrium isotherm studies for the uptake of cadmium and lead ions onto sugar beet pulp. Bioresour. Technol. 99: 3520-3527.

Perez-Marin, AB; Meseguer, V; Zapata, JF; Ortuno, M; Aguilar, J (2007). Removal of cadmium from aqueous solutions by adsorption onto orange waste. J Hazard. Mater. 139: 122-131.

Qaiser, S; Saleemi, AR; Ahmad, MM (2007). Heavy metal uptake by agro based waste materials. Electronic J. of Biotechnol. 10(3): 1-8.

Rao, KS; Anand, S; Venkateswarly, P (2010). Review on cadmium removal from aqueous solutions. Asorption Sci. and Technol. 28(2): 163-178.

Saravanane, R; Sundararajau, T; Sivamurthyreddy, SS (2002). Efficiency of chemically modified low cost adsorbents for the removal of Heavy Metals from Wastewater: A Comparative Study. Indian J. Env. Health. 44: 78-81.

Saueprasearsit, P ; Nuanjaraen, M ; Chinlapa, M (2010). Biosorption of lead $\left(\mathrm{Pb}^{2+}\right)$ by Luffa cylindrical fibre. Environ. Res. J. 4(1): 157166.

Schumann, K (1990). The toxicological estimation of the heavy metal content $(\mathrm{Cd}, \mathrm{Hg}, \mathrm{Pb})$ in food for infants and small children. $Z$ Ernahrungswiss, 29: 54-73.
Sharawy, H; Ossman, ME; Mansour, MS (2013). Kinetics modeling and adsorption isotherm studies for $\mathrm{Cr}$ (III) removal using boehmite nano-powder. Intern. J. Chem. Biol. Sci. 3: 9-18.

Sharma, YC (2003). Cr (VI) removal from industrial effluents by adsorption of an indigenous lowcost material. Colloids Surf. A. 215(1-3): 155162.

Shukla, A; Zhang, YH; Dubey, P; Margrave, JL; Shukla, SS (2002). The role of sawdust in the removal of unwanted materials from water. $J$. Hazard. Mater. B. 95: 137-152.

Sirajudeen, J; Naveen, J; Arul Manikandan, S; Mohamed Mubashir, MM (2013). Removal of chromium (VI) from aqueous solution by using citrus limetta peel as an adsorbent. Der Chemica Sinica. 4(2): 133-143.

Sun, G; Shi, W (1998). Sunflower stalks as adsorbents for the removal of metal ions from waste water. Ind. Eng. Chem. Res. 37: 13241328.

Vinodhini, V; Das, N (2010). Relevant approach to assess the performance of sawdust as adsorbent of chromium (VI) ions from aqueous solution. Int. J. Environ. Sci. Tech. 7(1) : 85-92.

Wasewar, KL; Kumar, S; Prasad, B (2009). Adsorption of Tin using granular activated carbon. J. of Environ. Prot. Sci. 3: 41-52.

Zafar, MN; Nadeem, R; Hanif, MN (2006). Biosorption of nickel from protonated rice bran. J. Hazard. Mater. 143: 478-485.

Zvinowanda, CM ; Okonkwo, JO ; Agyei, NM ; Staden, MV ; Jordaan W ; Kharebe, BV (2010). Recovery of lead (II) from aqueous solution by Zea mays tassel biosorption. Am. J. Biochem. Biotechnol. 6(1): 1-10.

Zvinowanda, CM; Okonkwo, JO; Shabalala, PN; Agyei, NM (2009). A novel absorbent for heavy metal remediation in aqueous environments. Int. J. Environ. Sci. and Technol. 6(3): 425-434. 